\title{
U-Al Alloy Charge Makeup Equation
}

by

F. C. Rhode

E. I. du Pont de Nemours and Company

Savannah River Site

Aiken, South Carolina 29808
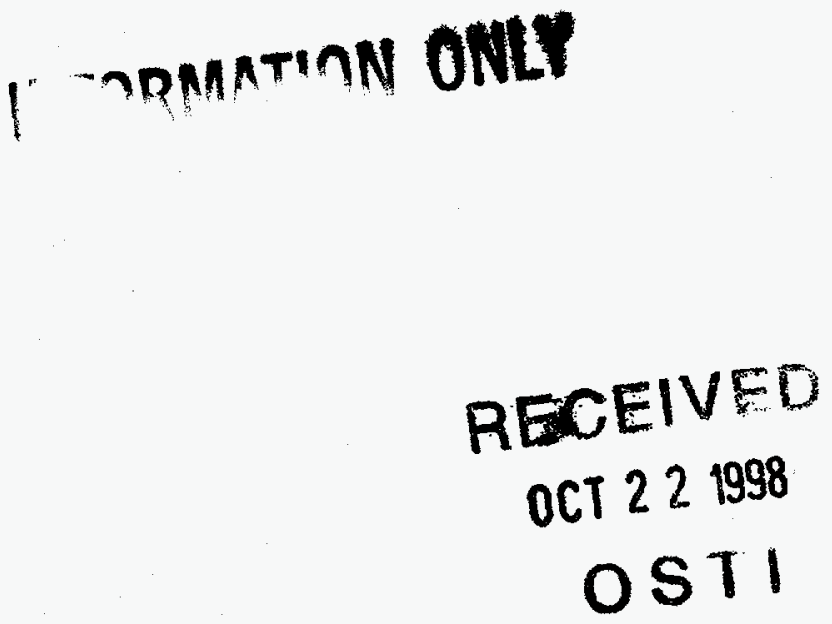

DISCLAIMER

\begin{abstract}
This report was prepared as an account of work sponsored by an agency of the United States Government. Neither the United States Government nor any agency thereof, nor any of their empleyees, makes any warranty, express or implied, or assumes any legal liability or responsibility for the accuracy, completeness, or usefulness of any information, apparatus, product, or process disclosed, or represents that its use would not infringe privately owned rights. Reference herein to any specific commercial product, process, or service by trade name, trademark, manufacturer, or otherwise does not necessarily constitute or imply its endorsement, recommendation, or favoring by the United States Government or any agency thereof. The views and opinions of authors expressed herein do not necessarily state or reflect those of the United States Government or any agency thereof.
\end{abstract}

DOE Contract No.

This paper was prepared in connection with work done under the above contract number with the $U$. S. Department of Energy. By acceptance of this paper, the publisher and/or recipient acknowledges the U. S. Government's right to retain a nonexclusive, royalty-free license in and to any copyright covering this paper, along with the right to reproduce and to authorize others to reproduce all or part of the copyrighted paper. 


\section{DISCLAIMER}

Portions of this document may be illegible in electronic image products. Images are produced from the best available original document. 


\section{INTER-OFEICE MEMORANDUM \\ SAVANNAH RIVER PLANT}

December 13, 1988

DPSP $-88-71-22$

INFORMATION ONLY

TO: T. P. VARALLO, 321-M

RAW MATERIALS ENGINEERING \& TECHNOLOGY

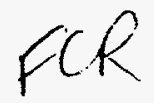

FROM: F. C. RHODE, 320-5M

RAW MATERIALS ENGINEERING \& TECHNOLOGY

RECEIVED

OCT 221998

OSTI

\section{U-AI ATIOY CHARGE MAKEUP EOUATION}

\section{Summary}

This memorandum documents an alternative equation for calculation of U-Al alloy casting compositions in Building 321-M. This equation confirms the results of another, undocumented equation that has been used in the past.

\section{Discussion}

The $235 \mathrm{U}$ content in fuel tubes $\left(\mathrm{g}^{235} \mathrm{U} / \mathrm{ft}\right)$ is directly proportional to the $235 \mathrm{U}$ concentration $\left(\mathrm{g}^{235} \mathrm{U} / \mathrm{Cc}\right)$ in the $U-A l$ core alloy. In order to prepare enriched uranium metal, aluminum, and U-Al scrap for U-Al production melts, the overall alloy composition (wt: U-Al) must be calculated for the desired $235 \mathrm{U}$ concentration $\left(\mathrm{g}^{235} \mathrm{U} / \mathrm{Cc}\right.$ ) and uranium enrichment (wt: $235 \mathrm{U}$ ). In the past, Equation 1 has been used for these calculations.

Equation 1: $\quad$ Wt $\% \mathrm{U}-\mathrm{Al}=\frac{100\left(\mathrm{~g}^{235} \mathrm{U} / \mathrm{cc}\right)(88.19-1.12(\mathrm{f}))}{(71.08-1.11(\mathrm{f}))\left(\mathrm{g}^{235} \mathrm{U} / \mathrm{cc}\right)+(238.12-3.01(\mathrm{f}))(\mathrm{f})}$

Where $f=$ weight fraction of ${ }^{235} \mathrm{U}$ in the total uranium

$$
=\frac{1}{100} w t \%^{235} \mathrm{U}
$$

This equation was used to generate numerical tables that RMETD personnel use to specify the nominal U-Al alloy casting "recipes". This same equation is used by the Process Monitor computer for the $\mathrm{U}-\mathrm{Al}$ alloy casting charge makeup calculations. Although this 
DPSP $-88-71-22$

Page 2

December 13,1988

equation has been successfully used for years, its origin is undocumented. By substitution of selected values into Equation 1, it can be shown that the assumed value for the density of $\mathrm{U}-\mathrm{Al}_{4}$ is $6.06 \mathrm{~g} / \mathrm{cc}$. This is consistent with published data. Examination of the lower right hand term of the equation indicates that the enriched uranium is assumed to be a mixture of $235 \mathrm{U}$ and $238 \mathrm{U}$. However, without knowledge of all the original assumptions, it is not possible to reproduce the equation's derivation.

Equation 2 was derived to confirm the results of Equation 1 .

Equation 2: $\quad$ wt $\%$ U-Al $=\frac{100\left(\frac{g^{235} \mathrm{U} / \mathrm{cc}}{\mathrm{f}}\right)}{2.7+0.806\left(\frac{\mathrm{g}^{235} \mathrm{U} / \mathrm{cc}}{\mathrm{f}}\right)}$

The derivation of Equation 2 and the assumptions used are discussed in Appendix 1. Results using both equations for a range of U-Al alloy compositions are compared in Table 1 . In all cases, the two equations produce the same results to within 0.02 wt: $\mathrm{U}-\mathrm{Al}$.

Neither equation is exact $(e . g$. the effect of the actual uranium isotopic contents $234 \mathrm{U}, 235 \mathrm{U}, 236 \mathrm{U}$, and $238 \mathrm{U}$ on the U-Al 4 derisity is not considered, the actual density of $\mathrm{U}-\mathrm{Al}_{4}$ is not constant due to non-equillibrium or non-stochiometric compositions of the intermetalif compound). However, based on past manufacturing experience, either equation is sufficiently accurate for U-Al alloy casting charge makeup calculations. 
DPSP $-88-71-22$

Page 3

December 13, 1988

TABLE I

COMPARISON OF EOUATIONS 1 AND 2

wt: $\quad U-A I$

$g^{235} \mathrm{U} / \mathrm{cc}$

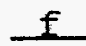

.66 (a)

$.63(b)$

.63 (b)

.93

.40

.5 (c)
32.99

19.78

29.23

3.86

33.74

68.86
Equation 2

32.98

19.77

29.22

3.86

33.73

68.84

(a) Typical Mark 22 composition

(b) Typical Mark 16B composition

(c) $100 \% \mathrm{U}-\mathrm{Al}_{4}$ 


\section{ASSUMPTION AND DERTVATION OE EOUATION 2}

When U-AI alloys solidify, the uranium is contained in intermetallic compounds surrounded by an aluminum matrix. Under equillibrium conditions, the uranium is present as $\mathrm{U}-\mathrm{Al} 4$. The density of this compound with natural uranium is $6.06 \mathrm{~g} / \mathrm{Cc}$ and it contains 68.81 wt: $\mathrm{U}$.

a) $w t \% \mathrm{U}$ in $\mathrm{U}-\mathrm{Al}_{4}=100\left[\frac{238.12}{4(26.98)+238.12}\right]=68.81$

Where: Atomic wt natural $\mathrm{U}=238.12$

Atomic wt aluminum $=26.98$

For any alioy containing up to 68.81 wto U-Al,

b) $\mathrm{g} \mathrm{U} / \mathrm{cc}=\frac{\mathrm{g}^{235 \mathrm{U} / \mathrm{cc}}}{\mathrm{f}}$

Where:

$$
\begin{aligned}
f & =\text { fraction of } 235 \mathrm{U} \text { in } \mathrm{U} \\
& =\frac{1}{100}\left(\mathrm{wt} \%{ }^{235} \mathrm{U}\right)
\end{aligned}
$$

c) $\mathrm{g} \mathrm{U}-\mathrm{Al} / \mathrm{cc}=\frac{1}{.6881}\left(\frac{\mathrm{g}^{235} \mathrm{U} / \mathrm{cc}}{\mathrm{f}}\right)$

d) $\quad V_{U-A I}=$ Volume fraction $U-A I$

$$
=\frac{1}{\sigma_{\mathrm{L}-\mathrm{AL}}}\left(\frac{1}{.6881}\right)\left(\frac{\mathrm{g}^{235} \mathrm{U} / \mathrm{cc}}{\mathrm{f}}\right)
$$

Where: $\quad \sigma_{\mathrm{U}-\mathrm{AI}}=$ density of natural $\mathrm{U}-\mathrm{Al}_{4}=6.06 \mathrm{~g} / \mathrm{cc}$.

e) $V_{A l}=$ Volume fraction free $\mathrm{Al}$ in matrix

$$
\begin{aligned}
& =1-\mathrm{V}_{\mathrm{U}-\mathrm{A} I} \\
& =1-\left(\frac{1}{6.06}\right)\left(\frac{1}{.6881}\right)\left(\frac{\mathrm{g}^{235} \mathrm{U} / \mathrm{cc}}{\mathrm{f}}\right)
\end{aligned}
$$


f) $\mathrm{g} A I / \mathrm{CC}=$ grams free aluminum in matrix

$$
\begin{aligned}
& =\sigma_{A I}\left(V_{A I}\right) \\
& =2.7\left(1-\left(\frac{1}{6.06}\right)\left(\frac{1}{.6881}\right)\left(\frac{g^{235} \mathrm{U} / \mathrm{cc}}{\mathrm{f}}\right)\right)
\end{aligned}
$$

Where: $\quad \sigma_{\mathrm{Al}}=$ density of aluminum $=2.7 \mathrm{~g} / \mathrm{cc}$

9)

$$
w t \% \mathrm{U}-\mathrm{Al}=\frac{100(\mathrm{gU} / \mathrm{cc})}{\mathrm{g} \mathrm{Al} / \mathrm{cc}+\mathrm{gU}-\mathrm{Al} / \mathrm{cc}}
$$

$$
=\frac{100\left(\frac{\mathrm{g}^{235} \mathrm{U} / \mathrm{cc}}{\mathrm{f}}\right)}{2.7\left(1-\left(\frac{1}{6.06}\right)\left(\frac{1}{.6881}\right)\left(\frac{\mathrm{g}^{235} \mathrm{U} / \mathrm{cc}}{\mathrm{f}}\right)\right)+\frac{1}{.6881}\left(\frac{\mathrm{g}^{235} \mathrm{U} / \mathrm{cc}}{\mathrm{f}}\right)}
$$

Equation 2: $\quad$ wt\% U-Al $=\frac{100\left(\frac{g^{235} \mathrm{U} / \mathrm{cc}}{\mathrm{f}}\right)}{2.7+0.806\left(\frac{\mathrm{g}^{235} \mathrm{U} / \mathrm{cc}}{\mathrm{f}}\right)}$

Note: Although the values assumed for the density of U-Al4 and the wt: $\mathrm{U}$ in $\mathrm{U}-\mathrm{Al}_{4}$ are based on natural uranium, these values will be in error by no more than $1.2 \%$ for any composition of enriched uranium. This has an insignificant effect (less than 0.005 wt: $U$ ) on the alloy composition determined by equation 2 . 